\title{
全層梁降伏型中低層鉄骨ラーメン構造構築のための 柱脚機構に関する部分架構モデルによる基礎実験 CYCLIC LOADING TEST FOR PARTIAL FRAMES WITH NEW COLUMN SUPPORT SYSTEM FOR MULTI-STORY STEEL MOMENT RESISTING STRUCTURES TO PERFORM BEAM YIELDING MECHANISM
}

\author{
金田勝徳*，木村祥 裕**, 六倉賢太 ${ }^{* * *}$, 角屋治 克 ${ }^{* * * *}$ \\ 渡辺亭****, 高橋邦広***** \\ Katsunori KANEDA, Yoshihiro KIMURA, Kenta MUTSUKURA, \\ Haruyoshi KADOYA, Toru WATANABE and Kunihiro TAKAHASHI
}

\begin{abstract}
In our previous papers, the new column support system is suggested, and it is shown that the columns base for the steel moment resisting frames never yield during large earthquake by the dynamic analyses. In this paper, the cyclic loading tests are performed for the partial steel frames with the embedded column base or our proposal new column support system. The columns for the proposal support system are shown to keep elastic by the large plastic range of the frames such as the angle of 0.05 , even though the columns for the embedded column base become as much plastic as the beams.
\end{abstract}

Keywords: Partial Steel Frames, Cyclic Loading Test, Column Yield, Column Support System, Hysteresis energy 部分架構，繰返し載荷実験，柱降伏，柱脚機構，履歴吸収エネルギ

\section{1. 序}

梁先行降伏型である鉄骨ラーメン構造において，柱脚の固定度が 高い埋め込み型柱脚を用いた場合，柱頭と柱脚で曲げモーメントの バランスが悪い最下層柱では，柱脚部曲げモーメントが柱頭に比べ て大きくなるため，脚部での損傷を許容せざるを得ない。また，露 出型柱脚を用いた場合，最下層の層関変形角が大きくなるため，柱 断面を大きくするか，柱脚固定度を上げる必要があり，埋め込み型 柱脚と同様，柱脚部での塑性化は避けられない。そこで，従来型の 埋め込久型柱脚や露出型柱脚に関する研究では柱脚での損傷メカニ ズムや耐力評価を行われており ${ }^{1)-4)}$ ，その成果が文献 5)にまとめられ ている。施工性の向上やリユースの観点から埋め込み型簡易柱脚や 露出型柱脚を提案した研究も見受けられるが 6)-8)，骨組の終局状態で の柱脚の損傷を防ぐシステムとは言い難い。

著者らは，これまでに基礎梁から $\mathrm{RC}$ 柱を立ち上げ，最下層の上部 鉄骨柱と下部 RC 柱を，曲げモーメントの伝達は行わず，せん断力と 軸力のみを伝達する簡易接合とし，その接合部（以降，鉄骨柱支点 部と称する）を地震時の曲げ応力の反曲点とする新しい柱脚機構を 提案した ${ }^{9110}$ 。このような新しい柱脚機構を適用寸ることで，中低層 鉄骨ラーメン骨組では，最下層柱脚部の塑性化を回避し，全層梁降 伏型を形成できることを明らかにした。さらに，設計地震荷重を超 える想定外の地震荷重に対して, 従来の埋め込久型柱脚の骨組では, 最下層柱脚部で最大耐力を迎え，柱崩壊を生じたものの，新しい柱
脚機構の骨組では梁で最大耐力を迎え, 柱での損傷を最大耐力以下 とする梁崩壊型メカニズムを形成できることを示した。そして，曲 げ応力の反曲点近傍に位置する鉄骨柱支点部に回転剛性が小さくな るようにアンカーボルトを配置すれば，鉄骨柱支点部はほぼピン接 合となることを骨組の静的増分解析で明らかにした。その際，鉄骨 柱支点部の設計には従来の露出型柱脚形式の場合を準用している ${ }^{5)}$ が，鉄骨柱支点部はピン接合に近い簡易な接合形式の方が望ましい。

本論文では， $\mathrm{RC}$ 基礎梁から $\mathrm{RC}$ 柱を立ち上げ，上部鉄骨柱と下部 $\mathrm{RC}$ 柱を簡易接合し，鉄骨柱支点部を地震時の曲げ応力の反曲点とす る新しい柱脚機構を実現するために，鉄骨柱支点部での損傷を防ぎ， ピン機構となる実用性の高い簡易ディテールを開発する。この機構 は, 柱脚が基礎梁と同様, RC 構造であり, 高い固定度を有する一方, 上部鉄骨柱と下部 RC 柱は柱断面の中心に設けられた 1 本のアンカ 一ボルトで接合し，鉄骨柱支点部での回転を許容する。この鉄骨柱 支点部では, 柱に作用するせん断力に対してはアンカーボルトやグ ラウトもしくは鋼板で抵抗する。

従来型の埋め込み型柱脚と本論文の提案型柱脚を有する柱梁部分 架構実験を行い，このような簡易ディテールを有する鉄骨柱支点部 のせん断力や曲げモーメントの忘力伝達機構を明らかにするととも に両者の保有性能を比較し, 中低層ラーメン骨組に対して全層梁降 伏型メカニズムを形成できる柱脚機構に関する基礎資料を提示する。

\footnotetext{
* 構造計画プラスワン 代表 日本大学 特任教授

** 東北大学大学院工学研究科 教授・博士 $($ 工学 $)$

*** 長崎大学大学院 大学院生

$* * * *$ 岡部侏) 博士 (工学)

****** 構造計画プラスワン

Prof., Nihon University, Structural Design PLUS ONE Co., Ltd.

Prof., Graduate School of Engineering, Tohoku University, Dr. Eng. Graduate Student, Graduate School of Engineering, Nagasaki University Okabe Co., Ltd., Dr. Eng.

Structural Design PLUS ONE Co., Ltd.
} 


\section{2. 新しい柱脚機構を有する部分架構の繰り返し載荷実験計画}

図 1 に提案型柱脚試験体及び実験装置概要を示す。図 1(a)は載荷装 置, 図 1(b)は試験体及び歪ゲージ貼付位置である。提案型柱脚機構を 有する柱梁部分架構は，最下層の $\mathrm{RC}$ 基礎梁， $\mathrm{RC}$ 柱，鉄骨柱支点部， 鉄骨柱及び梁で構成されている。加力点及び梁端はピン支持であり， 梁は鉛直支持材により支持されている。試験体は，実大スケールの 2/3 程度を想定しており, 鉄骨梁断面は H-194× $150 \times 6 \times 9$, 鉄骨柱断
面は $\square-200 \times 200 \times 9$ であり, 鉄骨柱, 梁の幅厚比は FA ランクである 11)。また， RC 柱断面を $\square-400 \times 400$ で主筋 $12-\mathrm{D} 19$ ，フープ筋 D10 で ピッチを $100 \mathrm{~mm}$ としている。 $\mathrm{RC}$ 柱の高さは $800 \mathrm{~mm}$ とし, 最下層高 さの $1 / 3$ 程度である。載荷は, 第 2 層柱の反曲点に相当する位置に 2000kN アクチュエータで制御している。図 1(a)に示すように，基礎 梁は曲げ変形及び水平移動を生じないように大きな断面とし，さら に抑え治具を取り付けている。また, それぞれの位置での降伏判定,

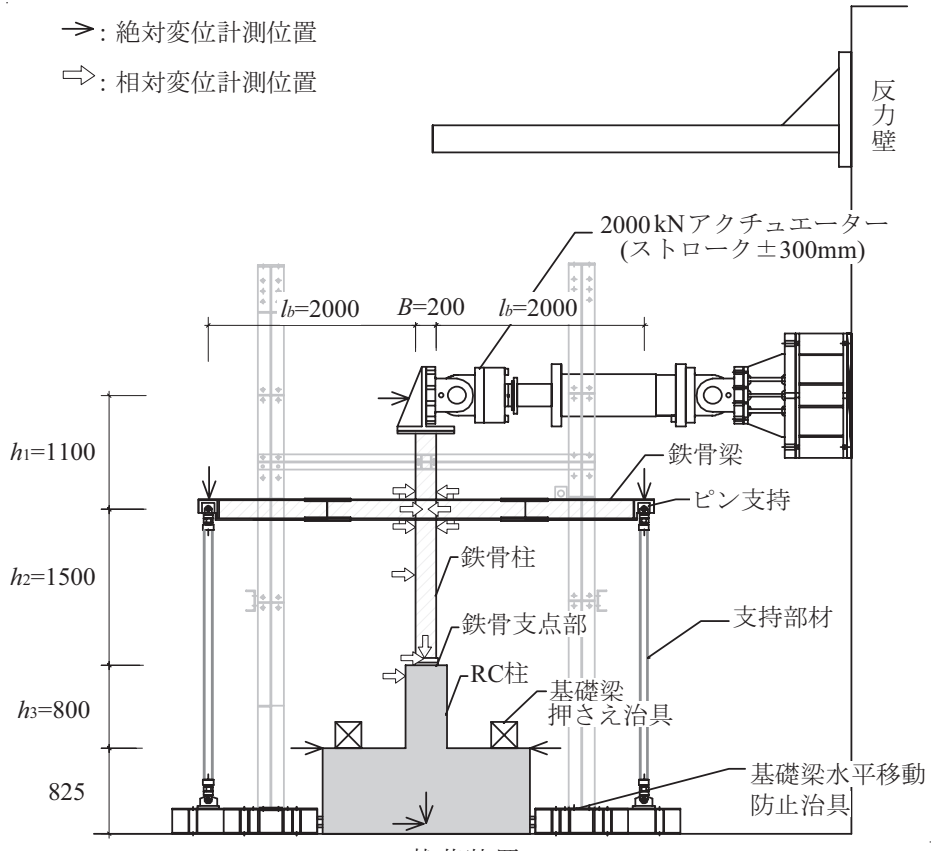

(a)載荷装置

図 1 部分架構載荷装置及び試験体

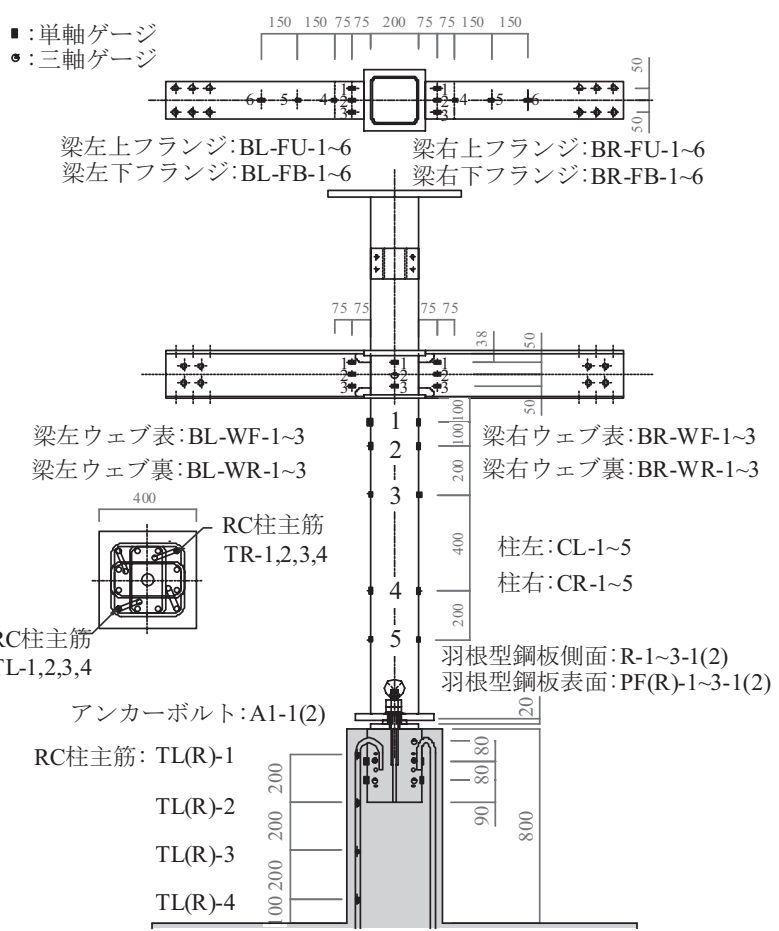

(b)試験体及び歪ゲージ貼付位置 (Cタイプ)

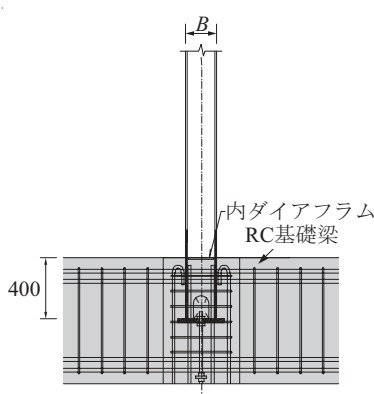

A-A 断面

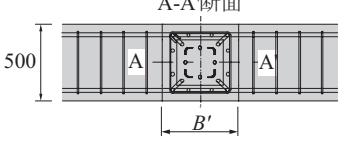

(a) $\mathrm{N}$ タイプ

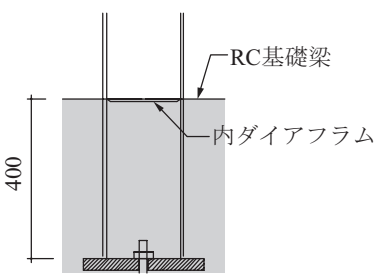

(a) $\mathrm{N}$ タプ

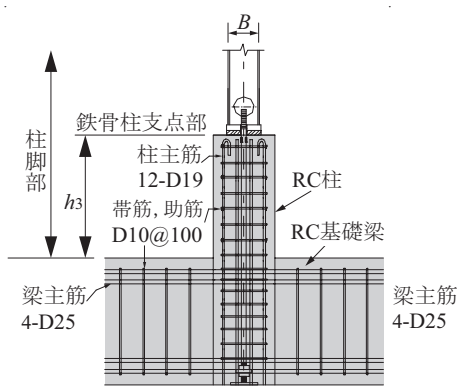

A-A'断面

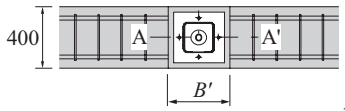

(b)A タイプ

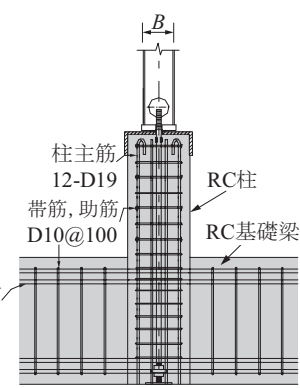

A-A 断面

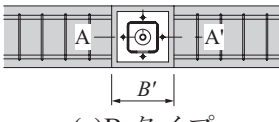

(c)B タイプ

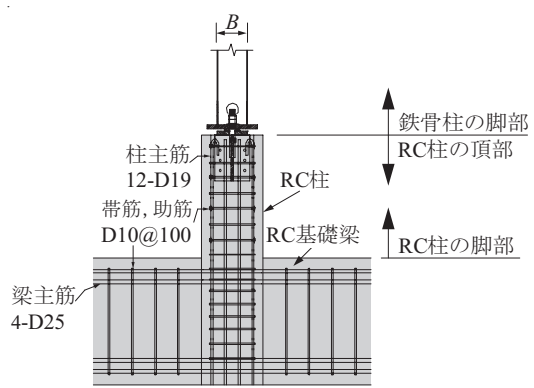

A-A'断面

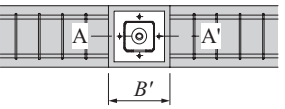

(d)C タイプ

図 2 鉄骨柱脚の形状例

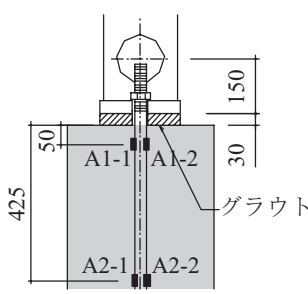

(b)A タイプ

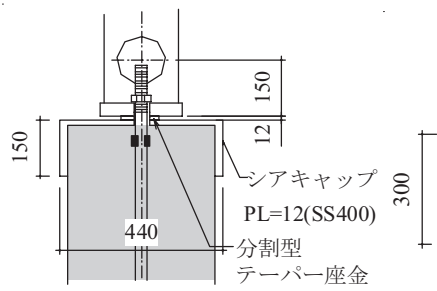

(c)B タイプ

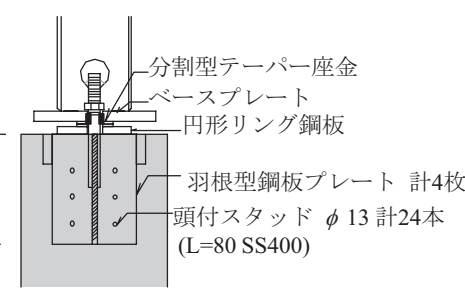

(d)C タイプ

図 3 柱脚部及び鉄骨柱支点部詳細 
塑性化進展状況, 歪分布を調べる目的で, 図 1(b)に示すような鉄骨梁, 鉄骨柱，アンカーボルト， RC 柱主筋に歪ゲージを貼付している。

図 2 に試験体の柱脚形状の概要を示す。図 2(a)は従来の埋め込み型 柱脚，図 2(b)〜 (d)は，本論文の提案型柱脚であり， $\mathrm{RC}$ 基礎梁から RC 柱を立ち上げ，鉄骨柱と接合したものである。文献 9)では，骨組 が終局時（最大層間変形角 0.03）において, 全層梁降伏型メカニズ ムを形成するためには，鉄骨柱支点部の高さは基礎梁断面中心から 梁断面中心までの高さに対して 0.5 程度が適切であることが示され ている。本論文では，さらに施工性を配慮して $\mathrm{RC}$ 柱と鉄骨柱の接合 の際に足場を組まなくても良い高さとして，基礎梁上端からの高さ として $h_{3}=0.34 h$ (基礎梁断面中心から梁断面中心までの高さに対して 0.53 $\left(h_{2}+h_{3}+825\right)$ ）とした。ここで， $h$ は架構高さ（加力点から基礎梁 上端までの高さ $\left.\left(h_{1}+h_{2}+h_{3}\right)\right)$ である。各タイプの基礎梁は, 構造設計 及び施工上, 要求される断面, 配筋とした。その結果, 図 2(b) (d) の本論文の提案型柱脚では基礎梁幅が $400 \mathrm{~mm}$ となるが，図 2(a)の埋 め込み型柱脚では埋込む鉄骨柱と基礎梁鉄筋との納まりから $500 \mathrm{~mm}$ を必要とする。これは, 基礎梁断面の設計における提案型柱脚の有 利な点となる。

図 3 に従来の埋め込み型柱脚の柱脚部と本論文で提案する柱脚の 鉄骨柱支点部の詳細を示す。図 3(a)は埋め込み型柱脚である。鉄骨柱 の埋め込み長さを柱の断面せいの 2 倍以上とし，400mm とした ${ }^{5)}$ 。 また, $\mathrm{RC}$ 基礎梁の支圧による鉄骨柱の局所板曲げ変形を防ぐために, $\mathrm{RC}$ 基礎梁の上端の位置に内ダイアフラムを設けた。図 3(b)の A タイ プでは RC 柱と鉄骨柱のベースプレートをアンカーボルトで接合し， 両者の間をグラウト注入している。これにより，鉄骨柱のせん断力 はアンカーボルトを介して RC 柱に伝達される。図 3(c)の B タイプで は RC 柱と鉄骨柱のベースプレートをアンカーボルトで接合し, 両者 の間に分割型テーパー座金を配置し， $\mathrm{RC}$ 柱の頂部に鋼板のシアキ ヤップを被せている。分割型テーパー座金の詳細は，図 4 に示す とおりであり, シアキャップ上面と隅肉溶接により接合している。 これらにより, 鉄骨柱のせん断力はアンカーボルトから分割型テー パー座金とシアキャップを介して RC 柱に伝達される。図 3(d)の C タイプでは RC 柱と鉄骨柱のベースプレートをアンカーボルトで接 合し，両者の間に直径 $200 \mathrm{~mm}$ 、厚さ $22 \mathrm{~mm}$ の円形リング鋼板を配置 した。A タイプ, B タイプに比べて $130 \mathrm{~mm}$ と短くしたアンカーボル
トに長さ $300 \mathrm{~mm}$ の羽根型鋼板 4 枚と, さらに鋼板にスタッドを取り 付けている。また, ベースプレート下面には直径 $100 \mathrm{~mm}$, 厚さ $9 \mathrm{~mm}$ の円形座金を隅肉溶接している。これらにより, 鉄骨柱のせん断力 はアンカーボルトから羽根型鋼板を介して RC 柱に伝達される。アン カーボルトについては, 鉄骨柱と RC 柱のせん断力のみを伝達すると 考え, 鉄骨梁が全塑性モーメント $M_{p b}$ もしくは終局モーメント $M_{u b}$ に達するときの鉄骨柱支点部に作用するせん断力以上となるように， アンカーボルトの全塑性耐力を下式より求め, アンカーボルトの径 を設定した。

$A_{a b} \sigma_{y a b} / \sqrt{3} \geq 2 M_{p b} /\left(h_{1}+h_{2}\right), \quad A_{a b} \sigma_{y a b} \geq 2 M_{u b} /\left(h_{1}+h_{2}\right)$

なお, 梁の全塑性モーメント時及び終局モーメント時の鉄骨柱 支点部のせん断力は $74.3 \mathrm{kN}, 105.1 \mathrm{kN}$ であることから, 梁の全塑 性モーメント時の柱のせん断力にほぼ等しい M24（せん断耐力 $73.8 \mathrm{kN})$, 及び梁の終局耐力時の柱のせん断力の 1.5 倍の耐力とな る M33（152.5kN）を選定した。鉄骨柱支点部ベースプレートのボ ルト孔径は A-1 タイプで 40mm，A-2, B, C タイプで $45 \mathrm{~mm}$ であり， ボルト孔とアンカーボルトねじ部との隙間に高強度無収縮グラウト を充填し, せん断力を直接アンカーボルトに伝達させている。アン カーボルトの長さについては, 文献 12)で露出型柱脚の回転剛性は定 着長の増加に反比例することが示されており，本論文における鉄骨 柱支点部をピン接合に近づけるために, A タイプ, B タイプの定着長 をできる限り長くし，1544mm（径の 50 倍程度）とした。なお，文 献 12)の露出型柱脚の回転剛性式を用いて回転剛性を算出したところ, 定着長が径の 50 倍の場合, 20 倍の場合と比べて, 剛性は $30 \%$ 程度と なる。ただし, 本試験体の鉄骨柱支点部は, 露出型柱脚とは異なり, アンカーボルトを断面中央に 1 本の夕配置し, アンカーボルトに引 張抵抗を期待していない。また, C タイプについては羽根型鋼板でせ ん断力を伝達させるために, A, B タイプと異なり, アンカーボルト 長を短く設定した。

また，図 3(b)〜(d)中の A〜C タイプの鉄骨柱の円形開口はアン カーボルトのナット締め付け用である。本試験体は縮小モデルで あり，実構造物ではこの開口は相対的に小さくなり，ナット締め 付け後は母材と同厚の鋼板でふさぐことも可能である。

図中には，鉄骨柱支点部近傍のアンカーボルトに貼付した歪ゲ ージ位置を併せて示している。

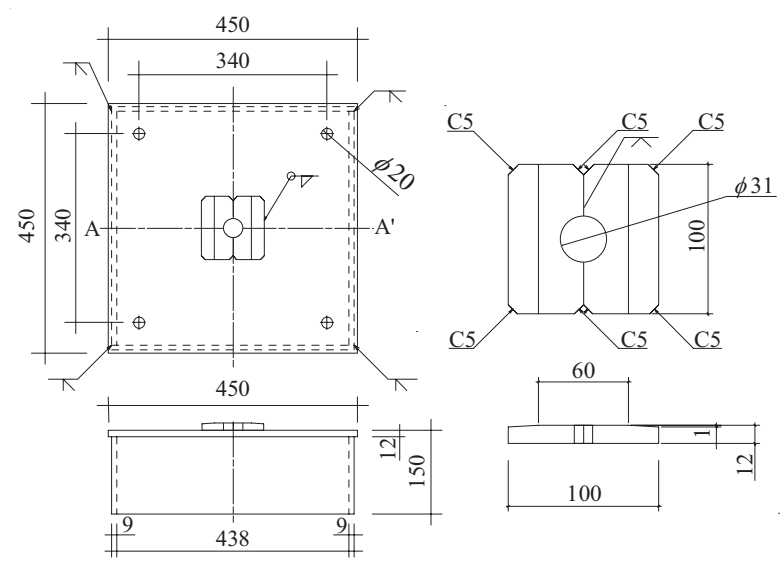

A-A' 断面

(a-1)シアキャップ

(a)Bタイプ

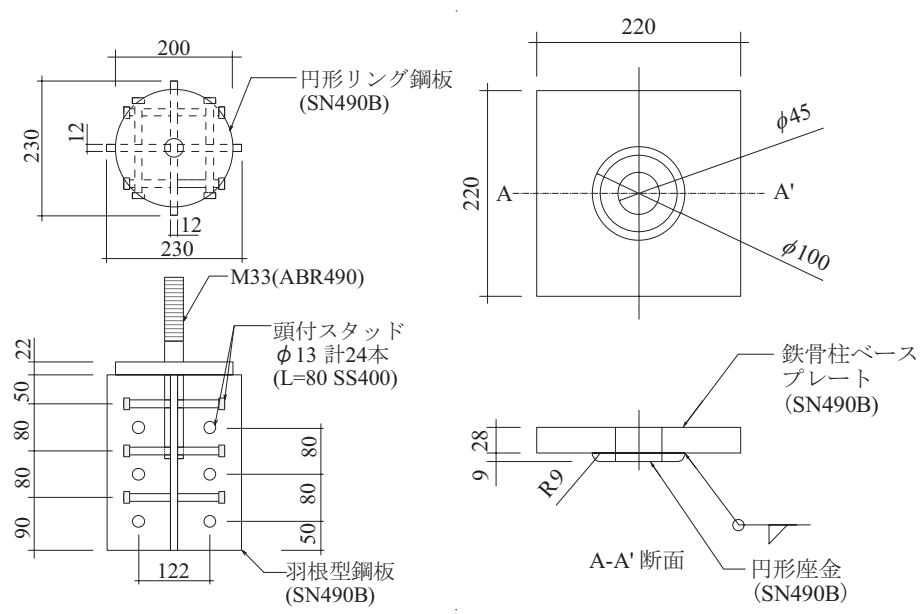

(b-1)羽根型鋼板

図４シアキャップ及び羽根型鋼板，鉄骨柱支点部ベースプレート詳細 
図4 にB タイプ及びCタイプ のシアキャップ及び习习习根型鋼板 の詳細を示す。図 4(a-1)のシア キャップについては, 上面板 $440 \times 440 \times 12$ と側面板 $440 \times 150 \times 9$ で構成されており, 側面板と上 面板を隅肉溶接している。材質 は SN400Bである。シアキャ ップの取り付け方法について は, RC 柱上面及び側面に対 して約 $10 \mathrm{~mm}$ のクリアランス を保持するように設置し，シ アキャップ上面四隅に設けた 直径 $20 \mathrm{~mm}$ の孔によりグラウ 卜を流し込み, 隙間を充填し た。図 4(a-2)の分割型テーパ 一座金については, $100 \times 100 \times 12$ の鋼板に直径 $34 \mathrm{~mm}$ の孔を空け, 2 枚に分 割している。板の中心から $30 \mathrm{~mm}$ と板の端 $50 \mathrm{~mm}$ の間を $0.05 \mathrm{rad}$ のテーパー加工とし, 座金孔 とアンカーボルト軸部のクリアランスは $0.5 \mathrm{~mm}$ である。なお, 鉄 骨柱支点部の許容回転角度は, 鉄骨柱ベースプレートが $\mathrm{RC}$ 柱上 端に当たらない, もしくは孔のクリアランスによりアンカーボル トが座金と当たらない範囲とすると，0.11 rad 程度までとなってい る。

図 4(b-1)の羽根型鋼板については, RC 柱と鉄骨柱のベースプレ ートを特殊アンカーボルトで接合し, 両者の間に直径 $200 \mathrm{~mm}$, 板 厚 $22 \mathrm{~mm}$ の円形リング鋼板を配置している。アンカーボルトの上 端部 $110 \mathrm{~mm}$ の範囲には M33 のねじを設け, その下部分には 300 $\times 115 \times 12$ の 4 枚の羽根型鋼板を完全溶け込み溶接としている。 また, 羽根型鋼板と円形リング鋼板を隅肉溶接している。羽根型 鋼板には頭付きスタッドを取り付けている。また, 図 4(b-2)の鉄 骨柱ベースプレート下面には, 直径 $100 \mathrm{~mm}$, 板厚 $9 \mathrm{~mm}$, 孔径 $45 \mathrm{~mm}$ の円形座金を隅肉溶接している。

表 1 に試験体リストを, 表 1 の横に試験体名を示している。試験 体は全部で 5 体である。埋め込み型柱脚の N タイプ以外には, 鉄骨 柱と $\mathrm{RC}$ 柱のせん断力の伝達にアンカーボルトを用いており, 材質は ABR490である。試験体名称は, 最初のアルファベットが柱脚形式を 示し, $\mathrm{A} \sim \mathrm{C}$ が本論文の提案型柱脚， $\mathrm{N}$ は埋め込み型柱脚である。 $\mathrm{A}$ タイプについては, アルファベットの次の数字がアンカーボルトの 径で 1 が M24 を，2 が M33 を示す。

表 2 に鋼材の材料特性, 表 3 にアンカーボルトの材料特性, 表 4 にコンクリートの材料特性を示寸。なお, C タイプについてはヤング 率を計測できなかったため,「鉄筋コンクリート構造計算規準・同解 説」 ${ }^{13}$ における圧縮強度による推定式を用いて算定した。鋼種は鉄骨 梁 SN400B，鉄骨柱 BCR295, RC 柱主筋 SD345, フープ筋 SD295 で ある。

図 5 に載荷プログラムを示す。載荷は漸増繰り返しであり, 加力 点における水平変位 $\delta_{T}$ を架構高さ $h\left(=h_{1}+h_{2}+h_{3}\right)$ で除した変形角
架構名称の記号

架構名

$$
\begin{aligned}
& \mathrm{T}^{\mathrm{A}-1} \text { [ 1:M24, 2:M33 } \\
& \text { (Aタイプのみ) } \\
& \text { D:根巻き型 } \\
& \mathrm{N} \text { :埋为込み型 } \\
& \mathrm{A}: \text { 提案型(アンカーボルトのみ) } \\
& \mathrm{B}: \text { 提案型(アンカーボルトトシアキャップ) } \\
& \mathrm{C} \text { :提案型(アンカーボルト+羽根型鋼板) }
\end{aligned}
$$

表 4 コンクリートの材料特性 $\left(\mathrm{N} / \mathrm{mm}^{2}\right)$

\begin{tabular}{|c|c|c|}
\hline 試験体名 & $E$ & $\sigma_{y}$ \\
\hline $\mathrm{A}-1, \mathrm{~A}-2$ & $24.3 \times 10^{3}$ & 27.1 \\
\hline $\mathrm{B}$ & $27.0 \times 10^{3}$ & 33.1 \\
\hline $\mathrm{C}$ & $25.2 \times 10^{3}$ & 35.5 \\
\hline
\end{tabular}

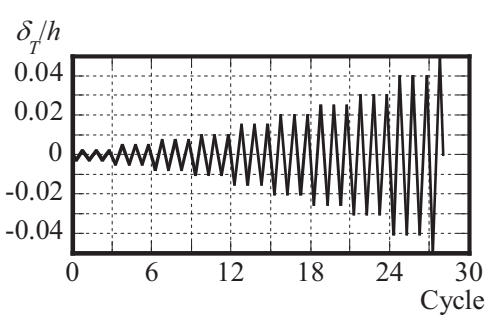

図 5 載荷履歴
$\delta_{I} / h=0.0025,0.005,0.0075,0.01,0.015,0.02,0.03$ で制御しており, 各変位振幅で 3 回ずつ正負交番繰返し載荷としている。なお, $\delta_{T} / h=0.03$ 時に著しい損傷が見られなかった場合, さらに $\delta_{T} / h=0.04$, 0.05 の変位振幅を与えている。

\section{3. 埋め込み型柱脚と本論文の提案型柱脚の柱梁部分架構試験体の 履歴性状 ( N , Aタイプ)}

図 6 に従来の埋め込み型柱脚である $\mathrm{N}$ タイプ, 本論文の提案型柱 脚である A タイプの部分架構モデルの加力点での荷重と変形角の関 係を示す。縦軸は水平荷重であり, 横軸は加力点における水平変位 $\delta_{T}$ を架構の高さ $h$ で除した変形角である。図中の $\nabla$ は梁降伏時, はアンカーボルト降伏時（ただし，Nタイプについては柱降伏時）を 示している。ここで, アンカーボルトに貼付した歪ゲージで最も大 きい歪值が表 2 のアンカーボルトの降伏応力より得られる降伏歪を 上回ったときをアンカーボルトの降伏と定義する。図 6(a)〜(c)は, そ れぞれ N, A-1, A-2 タイプの実験結果である。変形角 $\delta_{T} / h=0.03$ まで の範囲を実線で, それ以降の範囲を灰色点線で示している。埋め込 み型柱脚の $\mathrm{N}$ タイプでは, $\delta_{I} / h=0.013$ 程度で梁と柱脚部がほぼ同時 に降伏した。これは, 柱梁耐力比は 1.74 と比較的大きいものの, 柱 の埋め込み柱脚の固定度に対して柱上端の梁による回転拘束が小さ く, 柱の反曲点が基礎梁上端から $2 / 3$ 程度の高さとなり, 柱頭に比べ て柱脚部作用モーメントが大きくなったためである。ただし, 本実 験では鉛直荷重を与えておらず, 柱幅厚比は $B / t=22.2$ と比較的小さい ため, 柱脚部で塑性歪が進展し, $\delta_{I} / h=0.04$ 振幅時の第一サイクルの 負側で局部座屈を生じたものの, 最終的に耐力低下までは至らなか った。

一方, 本論文の提案型柱脚の部分架構について, A-1 タイプでは, $\delta_{I} / h=0.0034$ でアンカーボルトが降伏し， $\delta_{I} / h=0.011$ のときに梁が降 伏した。A-2 タイプでは， $\delta_{I} / h=0.010$ のときに梁が降伏し， $\delta_{I} / h=0.012$ でアンカーボルトも降伏した。A タイプは鉄骨柱と RC 柱の隙間をグ 
ラウトで充填したことで，鉄骨柱支点部 の固定度が高くなり，特にアンカーボル ト径が小さいA-1タイプではアンカーボ ルトの降伏により，鉄骨柱支点部でせん 断力が伝達できなくなったために, 梁の 作用モーメントも増加せず，結果として 梁の降伏が A-2 タイプよりも遅くなった ものと思われる。A-1 タイプについては, $\delta_{I} / h=0.03$ サイクルの時点で鉄骨柱支点 部に大きな損傷を生じたため, 載荷を終 了したものの, ボルト径の大きい A-2 タ イプについてはアンカーボルト降伏後 も変形角 $\delta_{T} / h=0.03$ まで安定した履歴を 描き,さらに大変形領域の $\delta_{I} / h=0.05$ まで 履歴は安定した紡鍾形となった。

図 7 に鉄骨梁の作用せん断力と梁端の 回転角の関係を示す。縦軸は, 梁端の支 持部材に貼付した歪ゲージより算出し た軸力を梁に作用するせん断力とした ものであり, 横軸は, 梁端の上下フラン ジに取り付けた変位計から算出した回 転角である。梁の全塑性モーメント $M_{p}$ を梁長 $l_{b}$ で除した全塑性曲げ耐力 $M_{p} / l_{b}$ を参考までに示している。実線である $\theta_{b}=0.01$ 程度までは全ての試験 体でほぼ同様の挙動を示し，さらに大変形領域まで載荷した $\mathrm{N}$ タイ プ及び $\mathrm{A}-2$ タイプの履歴曲線は最大 $\theta_{b}=0.03$ 程度となり, その範囲で 安定した紡錘形となった。

図 8 に鉄骨柱支点部の水平移動量を示寸。横軸は鉄骨柱支点部の 移動量 $\delta_{d}$ を架構の高さ $h$ で除した変形角としている。A-1 タイプでは, 早期に鉄骨柱支点部で水平移動を生じ, 繰り返し振幅の増加に伴い, 増大していく。A-2 タイプでは, 加力点の水平変形角 $\delta_{I} / h \leqq 0.03$ の範 囲（黒実線）では鉄骨柱支点部の移動はほとんど生じていないが， その後，急激に増加している。

図 9 に $\mathrm{RC}$ 柱の変形角を示す。横軸は $\mathrm{RC}$ 柱の水平変位 $\delta_{c}$ を架構の 高さ $h$ で除した $\mathrm{RC}$ 柱の変形角としている。加力点の変形角 $\delta_{T} / h \leqq 0.03$ の範囲（黒実線）では，A-1，A-2 タイプともに RC 柱の変形角は架 構全体の変形に対して小さいものの，A-2 タイプでは $\delta_{I} / h \geqq 0.03$ (灰 色破線) で RC 柱の変形角が一方向に増大している。これらの原因は, 鉄骨柱の回転に伴い，グラウトは圧壊し，さらに RC 柱にも大きなひ び割れが生じたためであり，正側に片振りしている。

図 10 に架構の変形角 $\delta_{T} / h=0.01,0.03,0.05$ のときのモーメント 分布を示す。プロットは, 図 1(b)における柱, 梁の各箇所の左右 （上下）に貼付した歪ゲージの值から曲げ歪を算出したものであ る。 RC 柱については断面保持を仮定し, 鉄筋に貼付した歪ゲー ジから曲げ歪を算出している。灰色線は $\delta_{T} / h=0.01$ のときの加力点 及び梁端の支持部材における反力から求めた曲げ歪分布である。 $\delta_{T} / h=0.01$ では, A-2 タイプで RC 柱の鉄筋歪でプロットと線が若 干異なっているものの，それ以外では各プロットと各線は概ね対 応しており，柱の各位置に貼付した歪ゲージ及び鉛直支持部材よ り求められる反力の計測は妥当であることが分かる。埋め込み柱

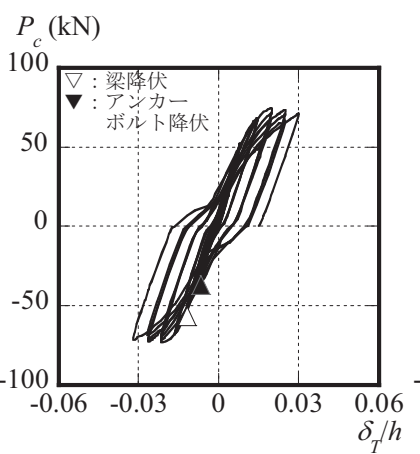

(b)A-1 タイプ

図 6 部分架構の荷重と変形角関係

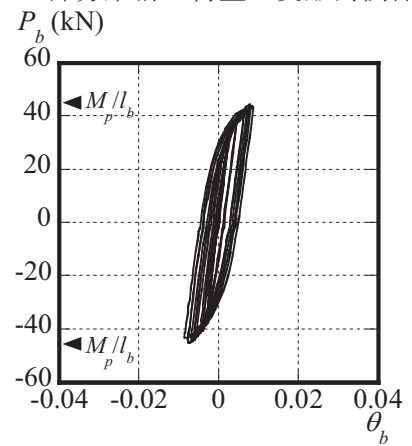

(b)A-1 タイプ

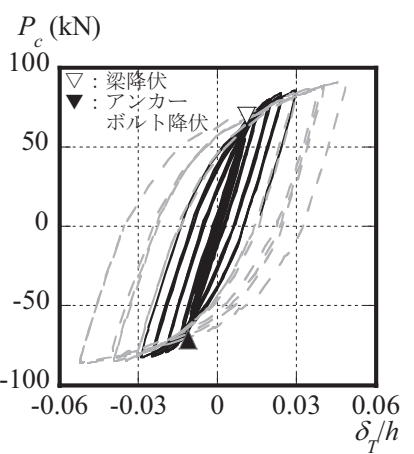

(c)A-2 タイプ

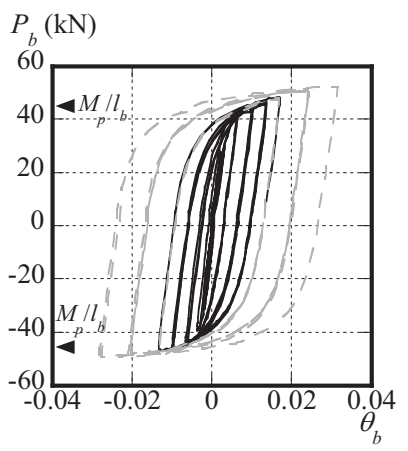

(c)A-2 タイプ
図 7 部分架構の荷重と鉄骨梁の変形角関係

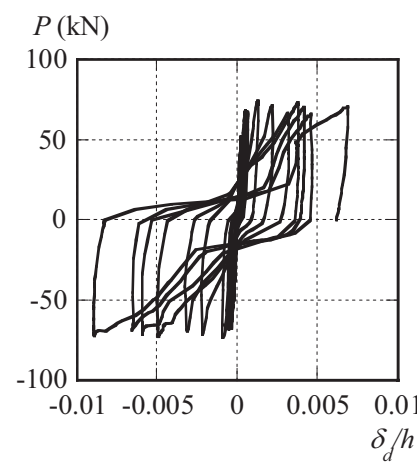

(a)A-1 タイブ
(b)A-2 タイプ $P(\mathrm{kN})$

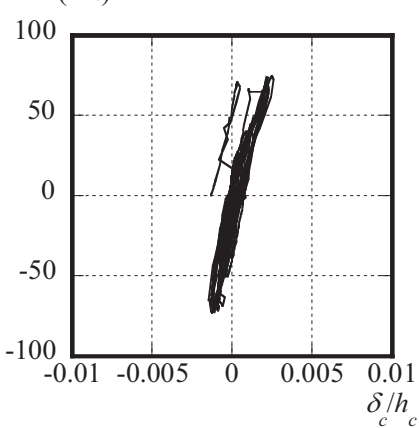

(a)A-1 タイプ

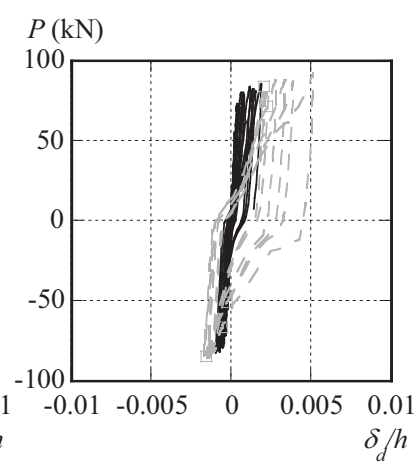

骨柱支点部移動量関係 $P(\mathrm{kN})$

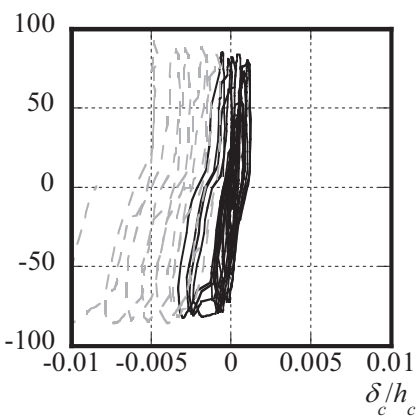

(b)A-2 タイプ
図 9 部分架構の荷重と $\mathrm{RC}$ 柱の変形角関係

脚の $\mathrm{N}$ タイプでは，鉄骨柱が弾性の範囲である $\delta_{T} / h=0.01$ では，柱 頭の曲げ歪は柱脚の半分程度であるが, 柱脚部の降伏後は柱脚部 のみで塑性歪が大きくなり， $\delta_{T} / h=0.03$ 時には $0.3 \%, \quad \delta_{T} / h=0.05$ 時 には $1.4 \% に$ 達した。一方, 提案型柱脚の A-1, A-2 タイプでは, 柱は弾性保持した。鉄骨柱支点部でモーメントがほぼ 0 に近く, $\mathrm{RC}$ 柱の柱脚, 鉄骨柱の柱頭でモーメントが制御されていること 
が分かる。

図 11 に $\mathrm{RC}$ 柱及び $\mathrm{RC}$ 基礎梁 のひび割れの進展状況を示す。 なお, 図 11(a)の埋め込み型柱脚 の $\mathrm{N}$ タイプについては, 鉄骨柱 周辺の基礎梁を示している。 $\mathrm{N}$ タイプでは柱脚に大きな曲げモ 一メントが生じるため, 変形角 $\delta_{T} / h=0.01$ で既に柱脚周辺で曲 げひび割れが生じているが，柱 脚部の曲げモーメントは増加し, 全塑性モーメントに達している。 その後, $\delta_{T} / h=0.04$ で柱脚部が局 部座屈し, ひび割れは若干進展 したが, $\delta_{T} / h=0.05$ まで柱脚部周 辺に大きなひび割れは見られな かった。A-1, A-2 タイプでは曲 げ変形に加えて, 鉄骨柱支点部 の回転に伴う支圧によるひび割 れが RC 柱頭で発生し, 特にア ンカーボルト径の大きい A-2 タ

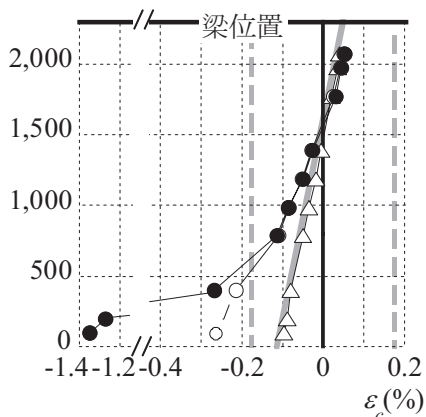

(a)Nタイプ

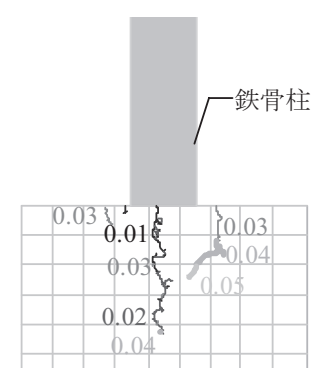

(a) $\mathrm{N}$ タプ

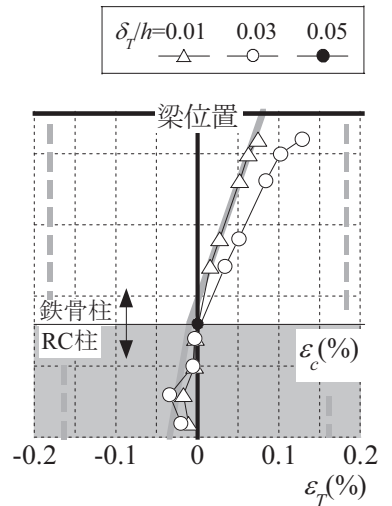

(b)A-1 タイプ

図 10 部分架構の曲げ歪分布

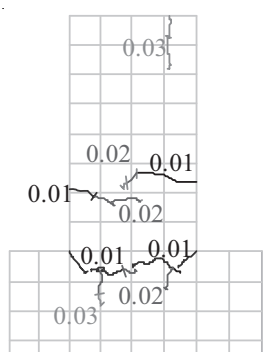

(b)A-1 タイプ

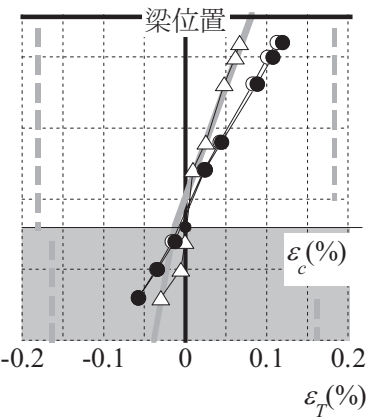

(c)A-2 タイプ

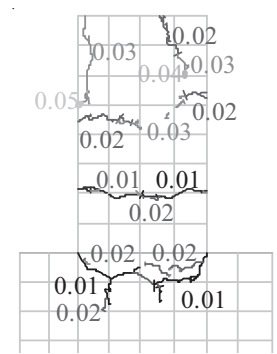

(c)A-2 タイプ
図 $11 \mathrm{RC}$ 柱及び $\mathrm{RC}$ 基礎梁のひび割れ進展状況

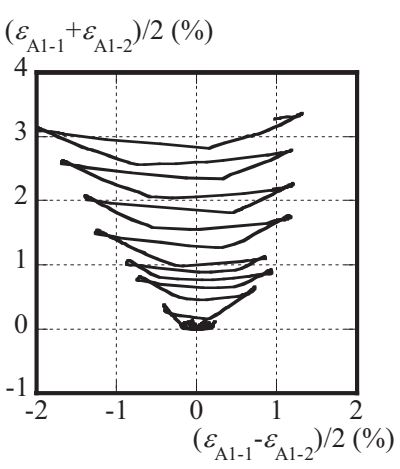

(a)A-1 タイプ

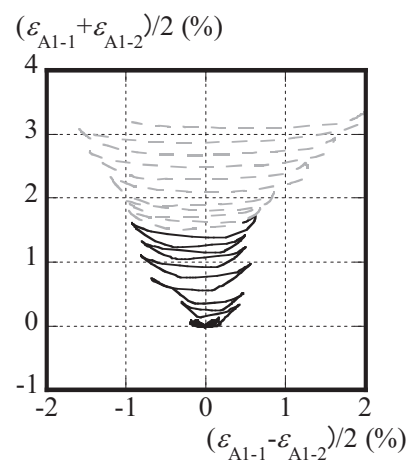

(b)A-2 タイプ
図 12 アンカーボルトの曲げ歪と軸歪関係

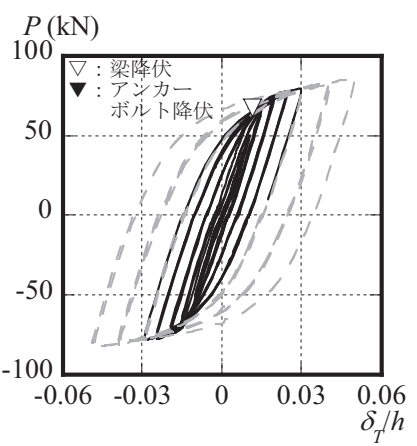

(a)B タイプ

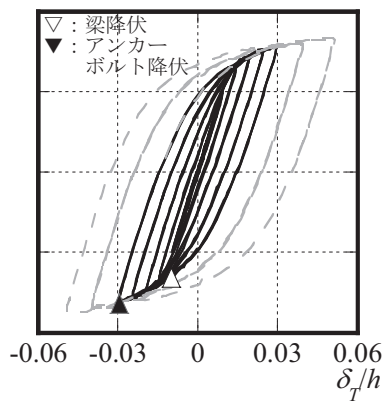

(b)C タイプ
図 13 部分架構の荷重と変形角関係

線）においても水平移動はほとんど生じておらず，シアキャップや 円形リング鋼板及び羽根型鋼板が鉄骨柱支点部のずれを抑えるのに, 有効に機能しているものと思われる。

図 15 に RC 柱の変形角を示す。図 9 の A-2 タイプでは鉄骨柱支点 部の回転変形に伴う支圧による $\mathrm{RC}$ 柱の局所的な圧壊により， $\delta_{T} / h \geqq$ 0.03 の範囲で変形角が増加したが，改良型の B, C タイプではほぼ線 
形関係を保持している。

図 16 にアンカーボルトの曲げ歪と軸歪の関係を示す。歪值は鉄 骨柱支点部に最も近い歪ゲージ（A1-1，A1-2）より算出したもの である。ただし， B タイプのアンカーボルトの歪ゲージ貼付位置 は RC 柱に埋め込まれた位置であり, Cタイプでは RC 上端の円形 リング鋼板と鉄骨柱ベースプレートの間であり，C タイプの歪貼 付位置の方がより応力集中を生じや寸い箇所である。図 12(b)の A-2 タイプとは異なり, B タイプでは $\delta_{I} / h=0.05$ までアンカーボル 卜は弾性保持した。 $\mathrm{B}$ タイプは, 鉄骨柱と $\mathrm{RC}$ 柱の間をグラウトの 代わりにシアキャップを挿入したことで, 載荷履歴が進展しても アンカーボルトの局所的な曲げ変形が抑えられた。そのため, ア ンカーボルトは鉄骨柱と RC 柱間でせん断力のみを負担すればよ く, 大変形領域まで弾性保持することが可能となった。 $\mathrm{RC}$ 柱内部 でアンカーボルトにシアプレートを取り付けた C タイプでは, $\delta_{T} / h=0.03$ までアンカーボルトは弾性保持し, その後 $\delta_{T} / h=0.04$ 程度 で降伏した。さらに, 大変形領域では歪ゲージは断線し, 計測不 可能となった。

なお，弾性領域である $\delta_{T} / h=0.01$ での，この位置でのアンカーボ ルトの曲げ歪值は, A-2 タイプの 0.096\%に対して B タイプの $0.049 \%$ と 5 割程度であり, シアキャップが応分のせん断力を負担 しているものと推測できる。また， $\mathrm{C}$ タイプの羽根型鋼板に貼付 した歪ゲージから羽根型鋼板によるせん断力の分担が確認できた が，羽根型鋼板のせん断歪の值は最大でも $0.04 \%$ 以下であった。

図 17 に，部分架構試験体の各部位の変形が第一層の変形角に寄与 した割合を示している。各図(a)〜(c)には, 変形角 $\delta_{I} / h=0.01,0.02,0.03$ のときの鉄骨柱の水平変位, 鉄骨柱支点部の水平移動量, $\mathrm{RC}$ 柱の水 平変位の割合である。ここで, 鉄骨柱の水平変位とは載荷点と鉄骨柱 支点部ベースプレートの水平変位の差, $\mathrm{RC}$ 柱の水平変位とは基礎梁 上端と $\mathrm{RC}$ 柱上端の水平変位の差とする。図中の数字は各部位の水平 変位を架構高さで除したものである。A-1タイプでは $\delta_{I} / h=0.01$ のき, 鉄骨柱支点部の移動量は，全体の $5 \%$ 程度であったが， $\delta_{I} / h=0.03$ のと きには $30 \%$ 程度にまで達する。A-2 タイプでも $\delta_{I} / h=0.01$ のとき, 鉄骨 柱支点部の移動量は A-1 タイプとほぼ等しいものの, $\delta_{I} / h=0.03$ のと きには $15 \%$ 程度になる。図 $16(\mathrm{c})$ の $\mathrm{B}, \mathrm{C}$ タイプでは $\delta_{I} / h=0.03$ まで值 にはほとんど変化がなく, B タイプでは $2 \%$ 程度, C タイプでは $5 \%$ 程 度である。
5. 柱梁部分架構試験体の損傷メカニズムと履歴吸収エネルギ

写真 1 に架構の変形角 $\delta_{T} / h=0.03$ のきの架構全体の変形状況を, 写真 2 に鉄骨柱脚部もしくは鉄骨柱支点部近傍の最終変形状況を

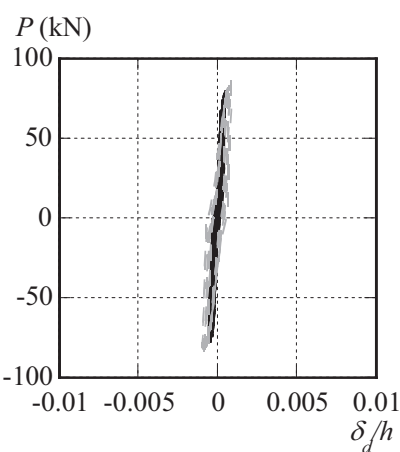

(a)B タイプ

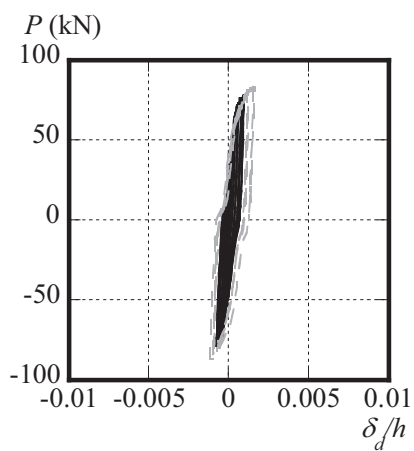

(b)C タイプ
$P(\mathrm{kN})$

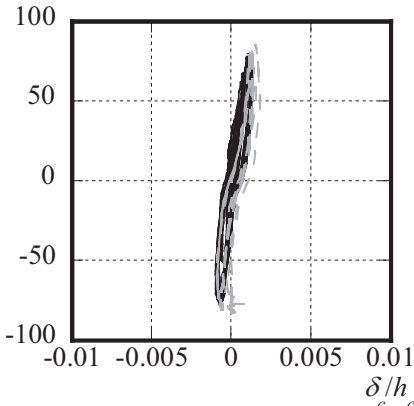

(a)B タイプ

\section{$P(\mathrm{kN})$}

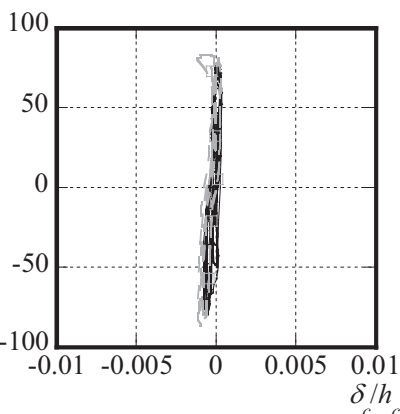

(b)C タイプ
図 15 部分架構の荷重と $\mathrm{RC}$ 柱の変形角関係

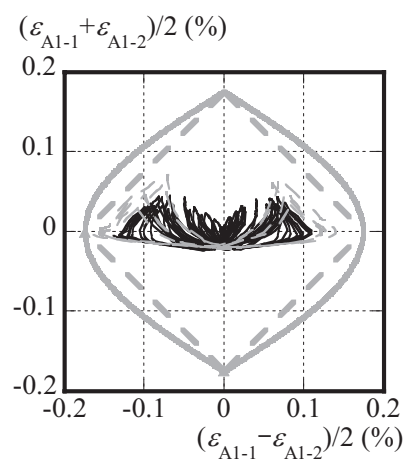

(a)B タイプ

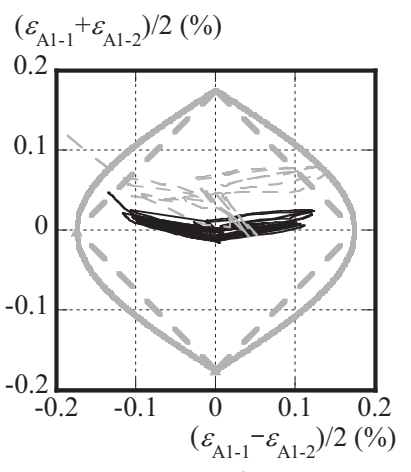

(b)C タイプ
図 16 アンカーボルトの曲げ歪と軸歪関係

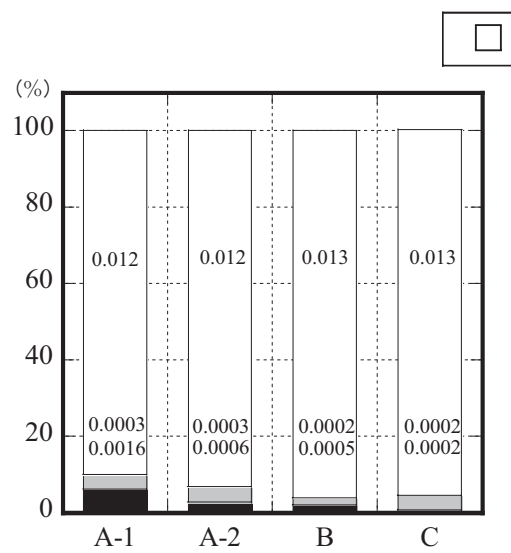

(a) $\delta_{T} / h=0.01$

$\square$ 鉄骨柱水平変位 $\square$ 鉄骨柱支点部水平移動量

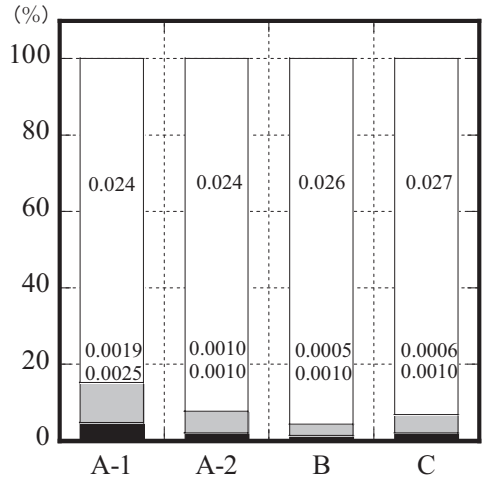

(b) $\delta_{T} / h=0.02$

$\mathrm{RC}$ 柱水平変位

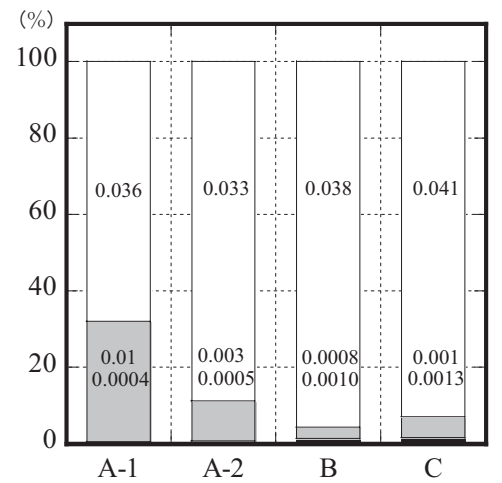

(c) $\delta_{T} / h=0.03$

図 17 第一層における各部位の変形角の割合 


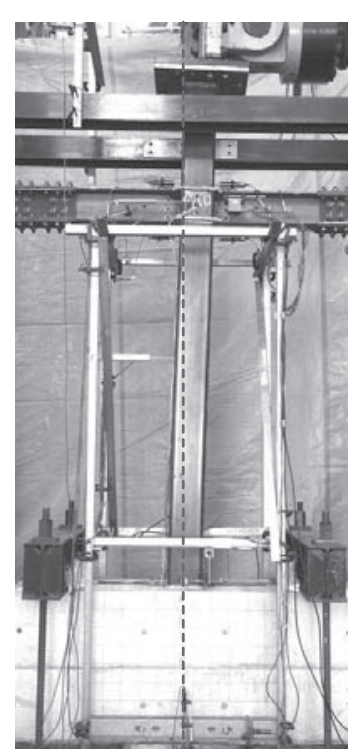

(a)Nタイプ

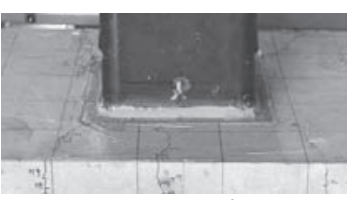

(a)Nタイプ

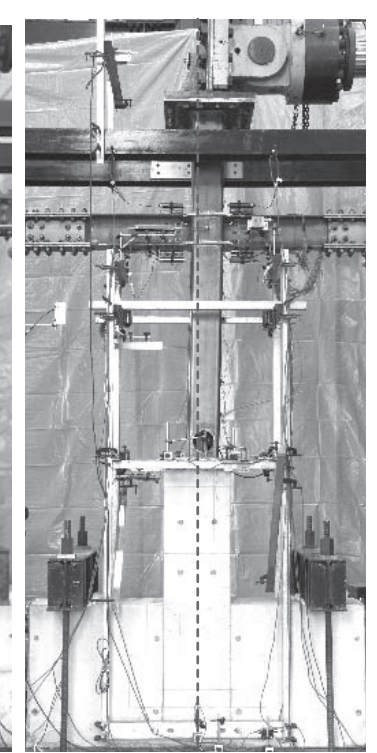

(b)A-1 タイプ

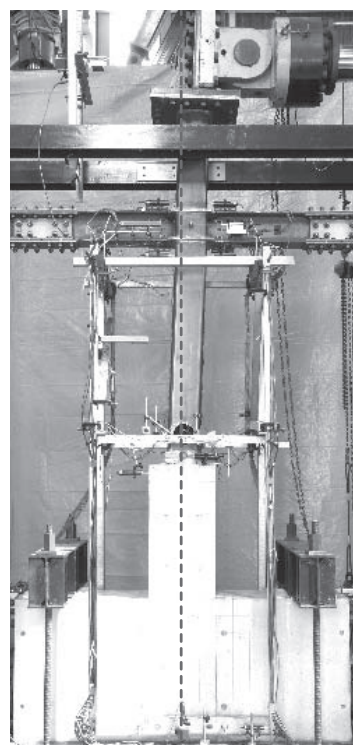

(c) $\mathrm{A}-2$ タイプ

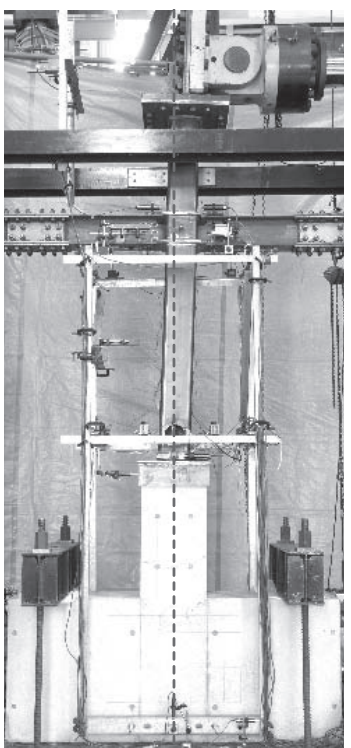

(d)B タイプ

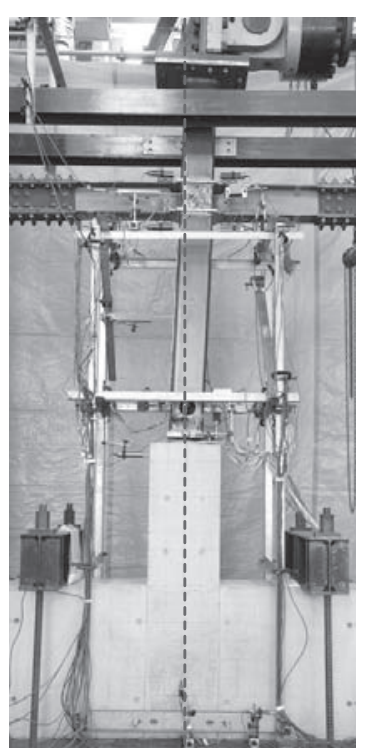

(e)C タイプ

写真 1 部分架構全体の変形状況 $\left(\delta_{T} / h=0.03\right)$

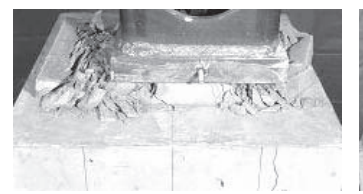

(b)A-1 タイプ

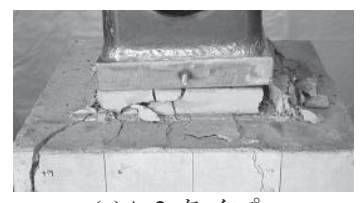

(c)A-2 タイプ

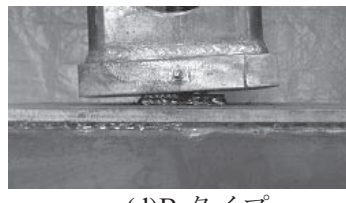

(d)B タイプ

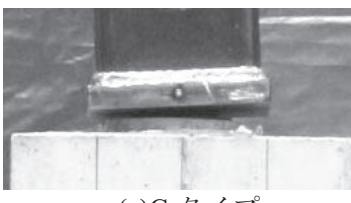

(e)C タイプ

写真 2 鉄骨柱支点部の最終変形状況

示す。(a)埋め込み型柱脚の $\mathrm{N}$ タイプについては, 写真 1 から柱脚 部を中心に柱の回転が生じており, 固定端となっていることが分 かるが, 写真 2 からは柱脚部での局部座屈波形は確認できない。

(b) (e)本論文の提案型柱脚については，写真 1 から鉄骨柱支点部 を中心に鉄骨柱が回転している様子が伺える。ただし，A-1 タイ プでは鉄骨柱と $\mathrm{RC}$ 柱で水平方向に大きなずれが生じている。写 真 2 から, アンカーボルトが曲げ変形し, 鉄骨柱が水平移動を生 じるとともに，鉄骨柱と RC 柱の間に注入したグラウトが鉄骨柱 の回転による支圧に耐えられず，圧壊している様子が伺える。A-2 タイプでも同様にグラウトの損傷が見られるが，アンカーボルト 径が大きいことから，アンカーボルトの曲げ変形は A-1 タイプよ りも小さい。また，鉄骨柱の移動量も小さく，グラウトの損傷は 外縁のみに留まっている。しかし, グラウト端部を基点とした RC 柱のひび割れが見られる。B，Cタイプでは鉄骨柱支点部の移動は ほとんど生じていない。そして，B タイプではシアキャップによ り，C タイプではアンカーボルトに取り付けた羽根型鋼板により $\mathrm{RC}$ 柱の局所的な損傷も抑制されている。なお, 鉄骨柱支点部でモ ーメントがほぼ 0 であり, 鉄骨柱支点部の円形開口は鉄骨柱支点 部の損傷を生じさせるものとはなっていない。また，開口に当て 板を溶接することによって補強することも可能であり, 開口が鉄 骨柱支点部に損傷を与えるものとはならない。

図 18 に鉄骨柱支点部の曲げモーメントと架構の変形角の関係 を示す。鉄骨柱支点部の曲げモーメントについては，鉄骨柱支点 部の近傍の鉄骨柱と RC 柱主筋の歪ゲージから算出した曲げモー メントを直線補間して求めている。鉄骨柱と $\mathrm{RC}$ 柱の間にグラウ トを注入した A-2 タイプと C タイプで作用モーメントが大きく,

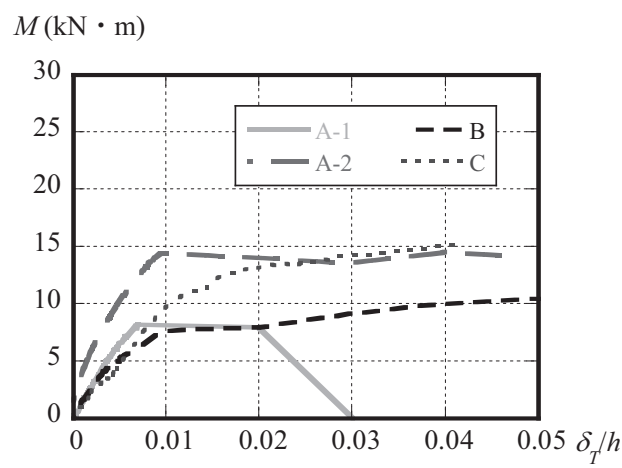

図 18 鉄骨支点部の曲げモーメントー変形角関係 $P(\mathrm{kN})$

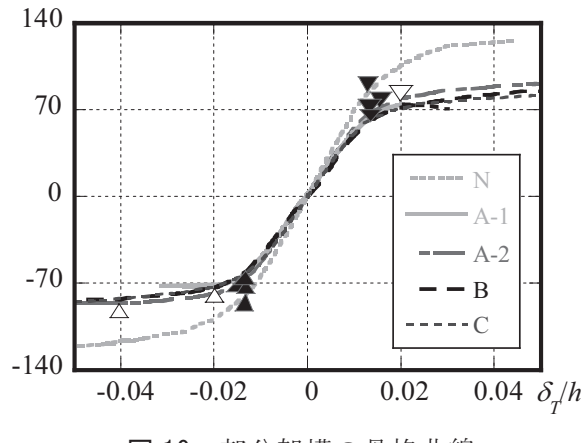

図 19 部分架構の骨格曲線

作用モーメントが低下した A-1 タイプを除けば，鉄骨柱と RC 柱 の間にシアキャップを用いた B タイプが最も小さい。グラウト注 入した A タイプでは，鉄骨柱支点部での鉄骨柱の回転をグラウト が拘束したため, 鉄骨柱支点部でのモーメントが大きくなったが, 


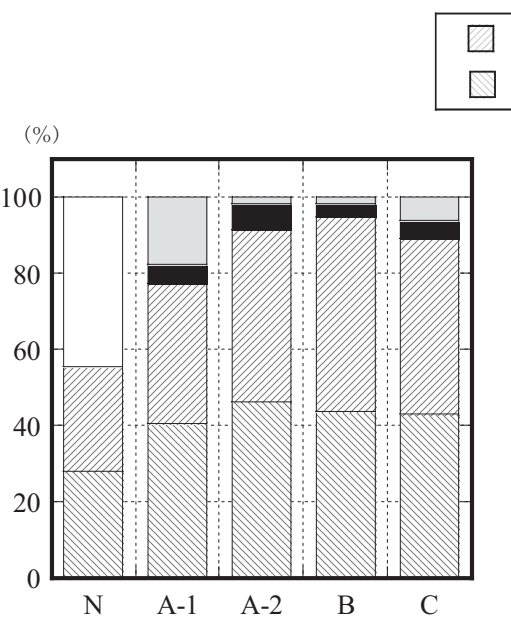

(a) $\delta_{\max } / h=0.02$

左梁 $\square$ 下部RC柱 $\square$ 鉄骨柱支点部移動量 上部鉄骨柱

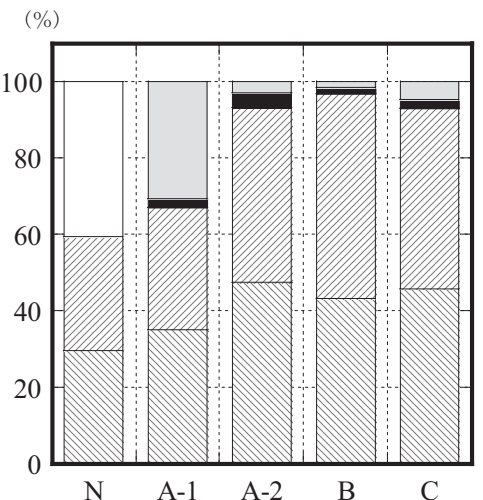

(b) $\delta_{\max } / h=0.03$

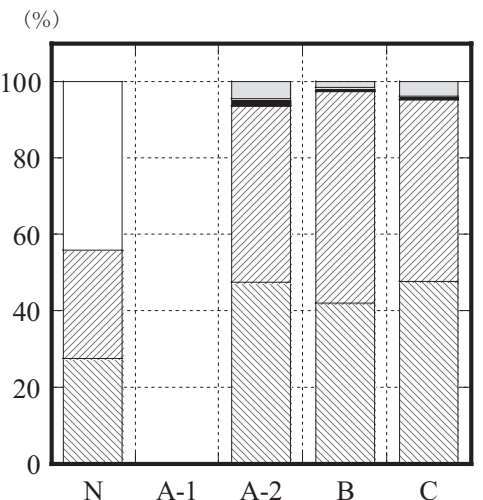

(c) $\delta_{\max } / h=0.05$

図 20 第一層における各部位の履歴吸収エネルギの割合

グラウトが圧壊することで作用モーメントが頭打ちとなった。A-1 タイプではアンカーボルトに対する作用曲げモーメントにより塑 性変形が大きくなり，アンカーボルトでもせん断力を負担できず， 鉄骨柱支点部のずれが生じたために作用モーメントは低下した。 いずれの試験体も $\mathrm{RC}$ 柱の柱脚部の最大作用モーメント $(80 \mathrm{kNm}$ 程度)に比べると，值は非常に小さく，ピン接合に近くなっている。

図 19 に各試験体の骨格曲線を示す。骨格曲線は, 図 6 及び図 13 の載荷履歴曲線において, 前の履歴曲線を越えた部分, 寸なわ ち架構が初めて経験する荷重レベルをつなぎ合わせたものである。 図中には，正側加力と負側加力をそれぞれ描いている。埋め込み 型柱脚の $\mathrm{N}$ タイプの初期剛性，降伏而力は他の提案型柱脚よりも 高いものの, N タイプでは梁端降伏後, 柱脚部で降伏し, その後, 塑性歪が大きく進展し，局部座屈を生じている。

提案型柱脚の場合，全ての試験体で初期剛性はほぼ等しいもの， B，Cタイプは A タイプよりも早期に梁端で降伏を生じた。A-1, A-2 タイプに比べて, 鉄骨柱支点部の回転剛性がさらに小さく, ピン接合に近い B，Cタイプでは，鉄骨柱支点部のピン機構によ り柱頭，柱脚にモーメントをほぼ均一に分配することで，梁のモ 一メントが N-1 よりも大きくなり，梁端の降伏を早める一方，柱 頭柱脚の作用モーメントの不均一を解消し，柱脚部での降伏を抑 え，耐力を保持した。しかし，アンカーボルト径が小さい A-1 タ イプでは鉄骨柱支点部で鉄骨柱と RC 柱の間に注入したグラウト が圧壊するとともに，アンカーボルトに局所的な曲げモーメント が作用したために，耐力低下を生じた。

図 20 に部分架構試験体の各部位の履歴吸収エネルギの割合を 示す。図 20(a)〜 (c) はそれぞれ変形角 $\delta_{T} / h=0.02, \delta_{T} / h=0.03, \delta_{T} / h=0.05$ のときの各試験体の履歴吸収エネルギの割合を棒グラフで示して いる。下から，それぞれ鉄骨梁 (右梁，左梁），鉄骨柱支点部， RC 柱，鉄骨柱についてである。鉄骨梁の履歴吸収エネルギについて は支持点でのせん断力に梁長を乗じたモーメントと梁端の回転角 より算出し，鉄骨柱支点部のずれ， $\mathrm{RC}$ 柱及び鉄骨柱の履歴吸収エ ネルギは加力点の荷重と $\mathrm{RC}$ 柱の水平変位及び鉄骨柱の水平変位 を乗じて算出している。(a)の $\delta_{T} / h=0.02$ のと, 埋め込み型柱脚の
$\mathrm{N}$ タイプでは梁と柱脚部で塑性歪を生じている。鉄骨柱の履歴吸 収エネルギの占める割合は $40 \%$ に達し，鉄骨梁では $60 \%$ 程度であ った。一方，本論文の提案型では $\delta_{T} / h=0.02$ のとき，A-1 タイプで 鉄骨梁の履歴吸収エネルギの占める割合は $75 \%$ 程度に留まり，鉄 骨柱支点部の水平移動に伴うエネルギ吸収が $20 \%$ 程度に達してい る。一方，その他の本論文の提案型柱脚の試験体では梁の履歴吸 収エネルギの占める割合は $90 \%$ に達している。改良型鉄骨柱支点 部の B, C タイプでは下部 RC 柱と上部鉄骨柱の損傷はほとんど生 じていない。そして, 変形角が大きくなるに従って, この傾向は 顕著になっていく。なお，A-1 については $\delta_{T} / h=0.03$ で鉄骨柱支点 部の損傷が大きくなり，載荷を終了したため， $\delta_{T} / h=0.05$ では值が 表示されていない。C タイプの鉄骨柱支点部の移動量の割合は, A-2 とほぼ等しくなっているが, これは, Cタイプ全体の履歴吸収 エネルギが A-2 よりも小さいためであり，鉄骨柱支点部の移動量 についてはCタイプの方が抑えられている。

以上より, RC 柱と鉄骨柱の断面中心にアンカーボルトを配置し， 鉄骨柱支点部近傍にせん断力を伝達できる羽根型鋼板を付与する ことで，鉄骨柱支点部ではほぼピン接合となる。そして，大変形 領域である $\delta_{T} / h \geqq 0.03$ においても鉄骨柱は弾性保持し, $\mathrm{RC}$ 柱の損 傷も抑えられ，梁降伏型メカニズムを形成できることを示した。

\section{6. 結}

本論文では, 地震時の降伏メカニズムが全層梁降伏型となる鉄骨 ラーメン構造を実現するための新しい柱脚機構を提案し, 柱梁部分 架構モデルの静的漸増繰返し載荷を行った。柱脚機構を含む部分架 構の剛性や耐力を検証し, さらに鉄骨柱支点部の応力伝達機構を明 らかにした。以下に得られた結論を示す。

1) 従来型の埋め込み型柱脚の場合, 変形角 0.013 程度で柱脚部が降 伏して大きな塑性歪を生じ, 最終的には柱脚部で局部座屈を生じ た。一方，本論文で提案する新しい柱脚機構の場合，鉄骨柱での 降伏を防ぎ, 大変形領域でも梁降伏型メカニズムを形成できるこ とを示した。

2) 鉄骨柱支点部のせん断力伝達機構をアンカーボルトとグラウト補 
強した A タイプの場合，アンカーボルトからのせん断力と鉄骨柱 支点部での回転による支圧により，グラウトが圧壊し，アンカー ボルトが曲げ変形を生じた。ボルト径を大きくすることでグラウ 卜の損傷を防ぎ, 変形角 0.03 までは安定した履歴挙動となりうる。

3) 鉄骨柱支点部のせん断力伝達機構をアンカーボルトとシアキャッ プとした B タイプの場合, 及び鉄骨柱支点部のせん断力伝達機構 をアンカーボルトと RC 柱に内蔵した羽根型鋼板とした C タイプ の場合, 変形角 0.05 の大変形領域までアンカーボルトはほぼ弾性 保持し，鉄骨柱支点部はほぼピン接合となった。そして，柱梁部 分架構試験体において鉄骨柱は弾性保持し，梁降伏型となり，鉄 骨梁の履歴吸収エネルギは 95\%に達し，安定した履歴挙動となる ことを示した。

今後, 柱軸力比, プレート形状やスタッドの配置等をパラメー タとした実験により, 羽根型鋼板タイプの鉄骨柱支点部近傍の忘 力伝達機構について検討していく。

\section{謝辞}

本研究は「平成 22 年度国土交通省建設技術研究開発助成制度」 による成果である。ここに，深く感謝の意を表す。

\section{参考文献}

1）秋山宏, 黒沢稔, 和国信之, 西村功 : 鋼構造埋込形式柱脚の強度と変 形，日本建築学会論文報告集，第 335 号，pp.45-53，1984.1

2) 森田耕次, 加藤勉, 田中淳夫, 藤田典正 : 埋込み形式柱脚の最大耐力 に関する実験的研究, 日本建築学会構造系論文報告集, 第 347 号, pp.65-74, 1985.1

3）大井謙一, 田中尚, 高梨晃一：鋼構造露出型柱脚部の終局而力，日本 建築学会論文報告集, 第 308 号, pp.14-23, 1981.10

4）九谷和秀，増田貫志：鉄骨構造露出形式柱脚部の終局耐力に関寸る実 験的研究, 日本建築学会構造系論文報告集, 第 433 号, pp.39-49, 1992.3

5）日本建築学会：鋼構造接合部設計指針 7 章 柱脚, pp.255-309, 2008.7

6）山田哲，岡田健，國岡恭子，薩川恵一：アングルを用いた露出型柱脚 の実験的研究, 日本建築学会構造系論文集, 第 514 号, pp.185-192, 1998.12

7）金子佳生，三橋博三，桐越一紀，諏訪内由紀 : 鋼緎維補強セメント系 複合材料を用いた鋼構造簡易柱脚，日本建築学会構造系論文集，第 600 号, pp.179-186, 2006.2

8）金子佳生，三橋博三，桐越一紀 : 鋼繊維補強セメント系複合材料を用 いた鋼構造柱脚, 日本建築学会構造系論文集, 第 619 号, pp.179-185, 2007.9

9）金田勝徳，木村祥裕，濱崎慎一，和田章 : 全層梁降伏型を目指した中 低層鉄骨ラーメン構造構築のための新しい柱脚機構の提案，日本建築 学会構造系論文集，第 75 巻第 654 号, pp.1537-1546, 2010.8

10）金田勝徳，木村祥裕，宮原直樹，和田章：新しい柱脚機構を有する中 低層鉄骨ラーメン架構の終局耐震能力，日本建築学会構造系論文集， 第 76 巻第 661 号, pp.649-658, 2011.3

11）国土交通省住宅局建築指導課，日本建築主事会議，日本建築セン夕 一：2001 年度版建築物の構造関係技術基準解説書，2001

12）日本建築学会：鋼構造接合部設計指針，2008

13）日本建築学会：鉄筋コンクリート構造計算規準・同解説，2010

14）日本建築学会 : 各種合成構造設計指針・解説，2010

\section{Appendix I 羽根型鋼板の設計方針}

鉄骨柱からの水平せん断力はアンカーボルトから支圧プレートに伝達され, 支 圧プレートから鉄筋コンクリート柱に支圧力として伝達されるものとする。せん断 力 $Q$ が作用する場合, 付図 1 に示すような三角形状に分布する支圧応力を仮定

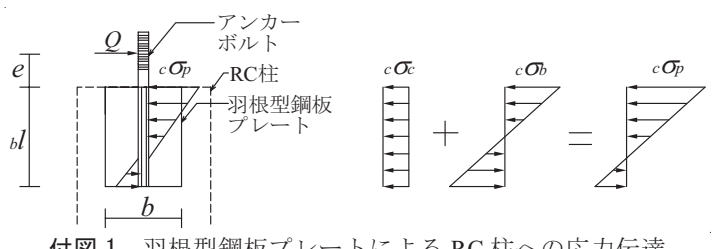

付図 1 羽根型鋼板プレートによる $\mathrm{RC}$ 柱への応力伝達

する。発生する支圧応力を ${ }_{c} \sigma_{p}$ とすると, せん断力による支圧応力 ${ }_{\mathrm{c}} \sigma_{c}$ と曲げモー メントによる支圧応力 ${ }_{c} \sigma_{b}$ を足し合わせることにより次式で求められる。

$$
{ }_{c} \sigma_{p}={ }_{c} \sigma_{c}+{ }_{c} \sigma_{b}
$$

ただし, ${ }_{c} \sigma_{c}, \sigma_{b}$ は次式に示すとおりである。

$$
\begin{aligned}
& { }_{c} \sigma_{c}=Q /\left(b_{b} l\right) \\
& \sigma_{b}=M / Z=M /\left(b_{b} l^{2} / 6\right), M=Q\left({ }_{b} l / 2+e\right)
\end{aligned}
$$

鉄骨梁が全塑性モーメントに達したときの鉄骨柱支点部に作用するせん断力 に対する支圧応力 $\mathrm{c} \sigma_{p}$ の最大值は $6.33 \mathrm{~N} / \mathrm{mm}^{2}$ であり, 表 4 のコンクリート強度以 下であることを確認している。

\section{Appendix II スタッドの設計方針}

柱に発生する軸力 $N$ は頭付スタッドのせん断耐力によって鉄筋コンクリ 一ト柱へ伝達される。頭付きスタッドの許容せん断力を,「各種合成構造設 計指針・解説」 ${ }^{14)}$ における 4.2 .2 節の(4) (7)式で算定し，本試験体は柱軸 力比 0.3 を想定してスタッド径と本数を決定した上で, 納まりや作業性を 確認した。なお，柱軸力比 0.3 のときの柱軸力に対するスタッドの許容せ

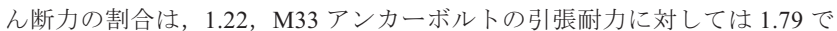
あり，スタッドは十分な耐力を有している。ただし，本実験では初期軸力 及び骨組の曲げ変形に伴う変動軸力を考慮していないことから, せん断力 と軸力が作用した場合の鉄骨柱支点部の応力伝達機構については, 今後検 討していく。

（2011年 1 月 10 日原稿受理，2011年 4 月15日採用決定） 